International scientific and practical conference. Cognum Publishing House. London, United Kingdom, 2021. P. 304-311.

14. Певні якості мислення у лікарів-інтернів різних фахів/ Стусь В.П., Схалов В.В., Моісеєнко М.М., Романюта I.А., Бараннік С.І. Урологія, 2020. т. 24. №2. C. 180-185. DOI: 10.26641/2307-5279.24.2.2020.208835

15. Новикова С.Г. Конфликтный больной на врачебном приеме. Как решить возникшие проблемы? Хирургическая практика, 2019. № 1(37). C.48-57. DOI: 10.17238/issn2223-2427.2019.1.48-57

16. Особливості психоемоційної підготовки лікарів- інтернів до самостійної праці як фахівців на рівні міжнародних вимог / Хавалкіна Л. М., Удальцова-Гродзинська К. О., Тимошенко Ю. В. Сучасна медична освіта: методологія, теорія, практика : матеріали Всеукр. навч.-наук. конф. $з$ міжнар. участю, м. Полтава (19 березня 2020 р.). Полтава, 2020. C. 235-237.

17. Схалов В.В., Кравець О.В., Богатирьова О.В. Принцип междисціпланарної інтеграції та апріорної мотивації в медицині невідкладних станів. Медичні перспективи, 2014, том XIX . № 2. Ч. 1. С. 103-105.

18. Yekhalov V. V., Sedinkin V. A. Present Day Deviations of Thinking of the Internship Doctors. International Journal of Science Annals, 2020. т.3. №1. C. 57-59. DOI:10.26697/ijsa

DOI https://doi.org/10.30525/978-9934-26-075-9-31

\title{
ЯКІСТЬ ЖИТТЯ У ЧОЛОВІКІВ, ХВОРИХ НА АНКІЛОЗИВНИЙ СПОНДИЛІТ, ЗВ'ЯЗОК З АКТИВНІСТЮ ЗАХВОРЮВАННЯ ТА СТРУКТУРНО-ФУНКЦІОНАЛЬНИМ СТАНОМ КІСТКОВОЇ ТКАНИНИ
}

\author{
Шевчук С. В. \\ доктор медичних наук, професор, \\ завідувач кафедри внутрішньої медицини № 2
}

Вінницький національний медичний університет імені М. І. Пирогова

Павлюк О. М.

аспірант кафедри внутрішньої медицини № 2

Вінницький національний медичний університет імені М. І. Пирогова м. Вінниця, Україна

Вступ. Оцінка якості життя (ЯЖ), що пов'язана зі здоров'ям, набуває все більшого значення при анкілозивниму спондиліті (АС). Біль, загальна 124 
скутість, втома є основними симптомами у хворих на $\mathrm{AC}$, які разом 3 притаманним для даного захворювання запальним компонентом ведуть до значних функціональних обмежень, які з часом порушують нормальну життєдіяльність [2, с. 857]. Згідно даних, у хворих з АС, в порівнянні з загальною популяцією, значно нижчий загальний показник якості життя [3, с. 605; 1, с. 311]. Однак, відомостей щодо якості життя за умов низької мінеральної щільності кісткової тканини (МЩКТ) та високої активності захворювання на сьогодні немає.

Мета. Вивчити показники якості життя за допомогою опитувальників SF-36, та HAQ у чоловіків хворих на AC та оцінити їх зв'язок 3 активністю захворювання та структурно-функціональним станом кісткової тканини.

Матеріали та методи. В основну групу було включено 105 чоловіків хворих на АC віком 40,7 $\pm 0,8$ роки, середня тривалість захворювання дорівнювала $8,7 \pm 0,5$ роки. Контрольна група включала 25 практично здорових осіб відповідного віку та статі. Діагноз АС встановлювали на основі критеріїв ASAS (2009). Всім пацієнтам проведено комплексне клініко-лабораторне обстеження. Клінічна активність АС визначалася відповідно до індексу BASDAI та за індексом ASDAS-СРБ. Для характеристики функціонального статусу та якості життя хворих на AC використано опитувальник HAQ та SF-36. МЩКТ поперекового відділу хребта та шийки стегна визначали методом двохенергетичної рентгенівської абсорбціометрії на апараті «Hologic Discovery Wi» (S/N 87227).

Результати. Дослідженням встановлено, що у чоловіків, хворих на АС відмічались достовірно нижчі показники як фізичного (37,3 $\pm 1,5$ бала) так і психічного (44,2 1,7 бала) компонентів здоров'я порівняно з групою контролю $(99,1 \pm 0,3 ; 97,4 \pm 0,7$ балів відповідно). Зокрема, аналізуючи субшкали, що утворюють фізичний компонент (PSH - SF-36) у хворих на $\mathrm{AC}$, найнижчий показник зафіксовано у «Рольового фізичного фун-

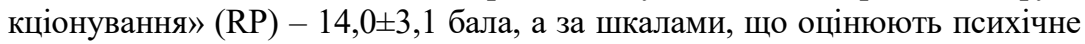
здоров'я (MSH - SF-36), істотно значимі відмінності виявлені для субшкали «Рольового емоційного функціонування (RE) - 22,2士3,9 бала. За опитувальником HAQ помірний ступінь відхилення відзначався в категоріях: «Досягання» $(1,38 \pm 0,1)$, «Мобільність, активність» $(1,37 \pm 0,1)$, «Одягання» $(1,3 \pm 0,1)$ та «Вставання» $(1,06 \pm 0,1)$.

У наступній частині дослідження ми проаналізували, як показники якості життя змінюються на фоні низької МЩКТ. Так, середні значення

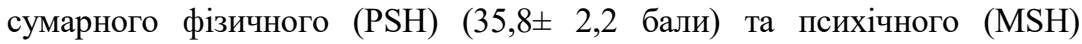
$(43,1 \pm 2,6$ бали) компонентів у хворих з остеопорозом були на $12,2-7,1 \%$ 
нижчими ніж у хворих зі збереженою МЩКТ (40,8 2,$7 ; 46,4 \pm 2,8$ балів відповідно). А показник загального здоров'я (GH) взагалі був достовірно нижчим у хворих з остеопорозом.

Показники якості життя тісно асоціювались 3 високою активністю запального процесу. Зокрема, в групі хворих 3 високим ступенем активності (BASDAI > 4) середній показник SF-36 (PSH) склав $34,3 \pm 1,3$ балів порівняно 3 44,7 $\pm 3,6$ балами у підгрупі 3 низькою активністю (BASDAI $<4$ балів), тобто сумарний фізичний компонент був нижче на 23,2\%. Сумарний психічний компонент здоров'я (MSH) також достовірно знижувався у групі з високим ступенем активності (BASDAI > 4). Подібні закономірності спостерігалися і за індексом ASDAS, де показники якості життя (SF-36 PSH та MSH) мали тенденцію до зниження в осіб з дуже високою активністю захворювання (ASDAS >3,5 балів). Додатковим підтвердженням негативного впливу високої активності захворювання на якість життя хворих $3 \mathrm{AC} є$ виявлений вірогідний кореляційний зв'язок між показниками SF-36 PSH, MSH та HAQ з індексами BASDAI ( $\mathrm{r}=-0,38 ;-0,30 ; 0,29)$ та ASDAS ( $\mathrm{r}=-0,20 ;-0,16 ; 0,27)$.

Висновок. Таким чином, у чоловіків хворих на АC наявне суттєве зниження показників якості життя за SF-36 (PSH та MSH) та HAQ, які тісно асоціюються 3 низькою МЩКТ та високою активністю захворювання.

\section{Література:}

1. Elolemy G, Aboughanima A, Ganeb S, Elziat H. Health-Related Quality of Life in Patients with Ankylosing Spondylitis: Relationship with Disease-Related Variables. Curr Rheumatol Rev. 2020; 16(4):311-318.

2. Kotsis K, Voulgari PV, Drosos AA, et al. . Health-related quality of life in patients with ankylosing spondylitis: a comprehensive review. Expert Rev Pharmacoecon Outcomes Res 2014; 14:857-872.

3. Ozdemir O. Quality of life in patients with ankylosing spondylitis: relationships with spinal mobility, disease activity and functional status. Rheumatol Int. 2011 May; 31(5):605-10. 